\title{
FAMILY SOCIAL CONTROL TO BULLYING CULTURE IN HIGH SCHOOL
}

\author{
Karnadi \\ State University of Jakarta \\ karnadi-pls@unj.ac.id
}

\begin{abstract}
This research goals is to given the descriptive brief about the form of interaction that applied between social agents, especially the senior and junior in High School (SMA). The research itself told about the transmition of bullying culture that happen in some High School in Jakarta, which done by seniors to their juniors. Also, this research will happen to know how the effectiveness of social crime prevention which applied by family agents as a primary social agent that should prevent any form of violence at school.
\end{abstract}

Keywords: Teenagers, Bullyinh, Labeling, Parents, Sub-culture, Norms, Family, Education.

Based on UU No.23/2002 about Children Saving, child define as someone who have not reached the age of 18 years old, including fetus. But, nowadays children with age 11-18 years old recognize as teenager by the society. In the society, a teenager already burdened by the expectations of norms and values created by the community, in the form of values and norms that area also imposed on adults but they also burdened with the limitations of being a teenager. Teenager who do not act according to the dominant values and norms will be consider as "naughty child", or in this case we call them delinquent.

A child can be described as delinquent when they meets the definition of the concept (Shoemaker, 2010. p.3): (1) status offender, is the deviant behavior as a crime, such as ditching and run away from home; (2) juvenile delinquency, is the deviant behavior if done by an adult is consider as a defined crime by the law, such as stealing or killing. There are few things behind that affect children to act which is defined as the act of "rouge" like the bad environment, efforts to gain status in the environment, efforts to get attention from adults, the weak linkage between the family, and so forth. This "delinquent" action done by the children is often associated with lower-class socioeconomic circumstances, but this should not longer be the only explanation as the cause of children on behaving as a "delinquent". If the act of delinquent is measured from the number of men who do so, it will be found similarities in the adolescent social class category (Shoemaker, 2009. p.51) 
Norms and values adopted by the teenager group nowadays is the result of findings from widespread contaminations of globalization. That cause easily obtained from different impressions in electronic and printed media such as television, internet, magazines, and so on. In fact, not necessarily the entire content therein can be accepted by their physical or psychological condition. The main key layout from this exposure caused by social control transmitted to every child. When the positive norms and values transmission are not going well, the control owned by children become weak. Thus, all form of different inputs that they accept will lead them to "naughty" behavior, which is defined by the society.

There can be different reasons that influence children to act deviant, for the example by making their own culture or we called it subculture. An individual under 18 years old basically categorized as teenager with unstable physical and psychological condition, because of that any children could get treatment and special care from the adults, even it their family or other adults around their environment.

Culture is created by teens can originate from social groups who are in school. One of this is bullying culture that often happens at school. They often use seniority cultural reasons as a justification to do it. Various reasons underlying the juvenile mischief can be caused due to lack of social control, either from the family or the school. Thus, they can easily transmitting bullying culture to continue to the juniors. This situation can be "compounded" when the teen came from uppermiddle class. Where teenagers, has a capacity of more materially to do whatever the want, compared with the teens from lower-middle class.

As the core of social agencies, parents, communities, schools and neighborhoods is the holder of an important role in preventing and countering "mischief" child. Their function is as an agent of transmission of values and norms, educate, and develop the positive behaviors that are considered by the community. However, if the relationship between the child and the social agents is not good, a child will seek refuge, which is generally in the form of gangs that would make them create or adopt a new culture that is different from the dominant society.

In this study, the concepts used are teenagers, norms, family and social crime prevention. Some theories also used to analyze the issues presented in this study, which are the labeling theory, the theory of conflict, containment theory, and the middle class. Explanation of the first concept is teens, there is a big element in the social construction in adolescence that the welfare of modern society has allowed the expansion indefinite period between childhood and adulthood, and the emergence of youth culture creation that has a certain distinctive characteristics (Steve Bruce and Steven Yearley, 2006. p.5). In this study is meant to teenagers are those aged 11-18 years who are members of the gangs in high school and have strong attachment to the group (peer group).

The next concept is norm, the rule has been agreed or the consensus of the dominant society. Norms are rules that regulate social behavior by the positive and 
negative (ie, reward and punishment). This is a manifestation of the values that exist within the community. Family concept used in this study was similar to what is proposed by Burgese. Where, family is a group united by ties of marriage, blood or adoption relationship, have interaction and communicate with each other and form of a household. Or to put it, the family is the basic social institution of which all agencies or other social institutions evolve, is in any society in the world and families is a universal human needs as well as being the most important center of activity in the lives of individuals (Narwoko, J.Dwi dan Suyanto, Bagong, 2004. p.14).

The next concept is social crime prevention, which is a crime prevention system using a social approach. All activities undertaken to prevent the causes of irregularities or crimes and eliminates the chance of an individual to commit an offense. Social crime prevention give more attention to the root causes of crime, especially the power that contribute to delinquency, drug abuse, and the number of problems associated with teenagers. Based on the premise that crime is caused by social problems in society, social crime prevention focus on programs and policies to improve the health, family life, education, housing, employment activities of individuals who are potential offenders (Rosenbaum, D.P., Lurigio, A.J. and Davis, R.C 1998, p.201).

In this study used some of the theory that have strong foundation in explaining reality that happen to youth subculture. These also used to explain the dynamic of the social reality, so that integrate many form of social theory to explain the reality of young subculture.

The first theory is labeling theory, they closely associated with teenage life. Labeling theory brings us to Chicago School thinking that is based on the idea of George Herbert Mead about symbolic interactionism in understanding social life centered on capabilities and human creativity in understanding one of each other (Jewkes and Letherby, 2002, p.26). Not only Mead, but also there some of big figures that are identical to this theory, among them Edwin Lemert and Howard Becker (Shoemaker, 2009. P.290). Labeling theory also become one of the famous theory and used by many criminology studies. In the book of Theories on Delinquency by Shoemaker, mentioned that basic idea of labeling theory is delinquent behavior that is influenced by many factors, one of which is the assumption and the formal label of a society that has influenced the views of others against individuals or groups.

Lemert with the concept of primary and secondary offense also contributed to the labeling in criminology studies. Lemert with these thoughts, stating that the primary offense of someone before their label from the public, but known to those closesr, while the secondary needed a long process, involvement, and acceptance of punishment for his actions, which finally got the label "deviant" (Shoemaker, 2009, p.260). 
Teens synonymous with labeling theory, because they receive special attention from adults of all behaviors and activities that they do. In particular, the peer group relationship and activities undertaken by their environment. The negative stereotype given to a group of peers to make these young people feel treated as criminals, because these group do not behave properly considered "conventional group", so as to motivate them to be the "deviant" group (Bernburg, Krohn, dan Craig J., 2006, p.70-71; Alan Bryman, 2004, p.402).

Conflict theory becomes a theory which is strongly associated with an explanation of delinquency. One explanation of the theory of conflict that can be used is the theory of cultural conflict by Sellin described as a rejection of norms and laws are interpreted as a "behavior" norm whose behave is based on the values of conventional culture (Shoemaker, 2009, p.298). Containment theory or the theory of the barrier have assumption about the "mischief", which is a form of nonconformity of social control prevailing in society to each of its members (Whitehead dan Steven P. 2013, p.87). Inner containment (Shoemaker, 2010 p.214) is a barrier system that associated by society to each individuals, which in turn requires a form of social control within the individual against himself. Outer containment (Shoemaker, 2009. p.123). is a barrier system, which is generally a set of rules adopted in the social environment that is outside of the individuals.

In short, this study aims to provide an overview of one form of interaction that is applied in one of the social agents, which is school. Where it happens the interactions between the seniors and the juniors in transmitting bullying subculture. In addition, this study also wanted to investigate the effectiveness of social crime prevention applied in families whose role as one of the primary social agents.

\section{METHOD}

This study used a qualitative approach because research done by digging depth facts about the phenomenon that will be discussed. This study focused on a subjective sense, definitions, symbols and descriptions of specific and special case. This qualitative study sought to capture aspects of the social world that is difficult to measure with numbers (Newman. 1997, p.329). In social studies, a qualitative approach has high flexibility, so that if in the process of the research found something more interesting to study, the it can participate studied in dept (Bryman, 2004, p.402). John Craswell, defines qualitative research methods as an approach or a search to understand and grasp a central symptom (Raco, 2001, p.81). While data collection techniques used in this study are in-depth interviews, observation, and also performed a literature review related research problems.

\section{RESULTS AND DISCUSSION}

In this study, the form of bullying is done by the students in high school is not just about physical violence. Other forms of acts of bullying such as verbal bullying, physical, and material is also often done. Bullying actors are largely the 
senior students. Violence perpetrated against junior from their seniors becomes the culture that seemed "interesting" by the students. Even the culture is rooted in high school and still involve seniors who had graduated.

Referring to the definition of culture in book Juvenile Delinquency A Sociological Approach by Bynum and Thompson, can be defined as the whole beliefs, values, attitudes, traditions, normative expectations, and other knowledge that is learned and passed down in each generation (Bynum, and Thompson, 2007. p.296). Generally, this kind of culture is most justified and already internalized within the community. Meanwhile, according to Tierney, subcultures is defined as a part on a culture, but has norms, values, beliefs, and behaviors that are different from the general culture of society (Tierney. p.191). In the case that happened at school, violent behavior which is part of the culture that has been adapted for decades by the students.

Bad behavior committed by male and female students can be considered as a proof of their attachment among the group. Such interactions which then creates a value that has been agreed by all the members of the group. Value created by the students in the school is considered to be not in conformity with the values that already agreed upon the general public. Thus, it is regarded as a subculture.

Acts of violence committed in schools, generally done by senior to their juniors. At the beginning, this was done as the part of "hazing" which was already entrenched in some schools in Indonesia, especially Jakarta. However, what makes it interesting from high school in Jakarta was hazing that still involves a senior who just graduated from high school. This research also found that, students have a certain group or gang which the "empower" to the next generation or in this case, their juniors.

Forms of delinquency or irregularities committed by middle school students are also part of their way to gain status in the community. In this case, students perpetrators of bullying attempts to transmit the value tobe attached as their identity. This value transmission is also an effort of the successor student with "bullying value: to get their identity in the new group. Which this thing will be considered as a big things for the juniors in their orientation period. This way reflecting the transmission theory lead by Shawn and Mc Kay, according to their lifestyle influential in transmitting it, so they will have an important status in the group. Ownership status being one of the main things for middle school students, through the status they feel that they have a place among their community.

In this research, we also saw a link between the subjects and their family. Family is the basic social institution of which all agencies or other social institutions evolve, is in any society the world and families is a universal human needs as well as being the most important center of activity in the lives of individuals. Family also has the important role in the lives of the interactions amongst the middle school students. 
In addition, the family also has another function, namely as a crime deterrent agent. Based on the understanding that crime is part of the social problems, family as a social agent first owned by the students certainly have the responsibility to give more attention to their child that also have the responsibility to committed crime. Social crime prevention give its focus on the program and the policies to raise up health, family life, education, housing, employment and environmental activities of individuals who are potential offenders (Rosenbaum, D.P., Lurigio, A.J. and Davis, R.C , 1998, p.201)

It can not be denied that teens need a surveillance from the very first of their social agents, and it is their family. However, this thing still can be found on all three subjects. Additionally, the three subjects on this research came from upper-middle class families. Where this issue, contrary to the public's understanding, that the crime can only be commit by perpetrators from lowermiddle class family. Of course, it is much different when considering that the majority of high school students in Jakarta is dominated by the children of the upper-middle class families.

The finding are in line with Parson's thought into background of journal written by England, where hedonism behavior that is not accounted by the children from middle-upper class be the main aspects of behavioral cause delinquent act. In this research, the junior from high school in Jakarta also held a number of money by the seniors. In addition to receiving specific acts of violence in the name of "orientation". Delinquent behavior done by children from upper-middle class is the result of interaction between some general aspects of the cultural system and the development of system that internalize in the children themselves, which then generates a functional norm in the end. Cultural development is done by the children due to the ambiguity of the status of the receipt. No doubt also, that the role of the family is also resulting in adolescents often experience role ambiguity that will be carried out during their daily activity in the wider community.

For the example, family from subject 1, especially his mother actually gave him permission to interact with many people, including those from their "hang out" places that surrounded by friends of the school. It's just a little bit contrary with who strictly forbid their children to associate with certain kind of community. The subject number 3, said that his family don't know anything about his involvement in groups that often commit "deviant" act. Although both parents also providing surveillance, informant 3 still get the permission to get together more often with his friends in school despite to do this quietly. While, on the subject number 2, do not have direct supervision from his family because they are outside of town. He said that he had been entrusted by the parents to live alone in Jakarta and indirectly had freed him to perform various activities that he wanted to do.

School should be a safe haven for the students. However, research conducted by the NGO Plan International Center for Research on Women (ICRW) released earlier in March 2015 pointed to the fact that $84 \%$ of children in Indonesia 
have experienced violence in school. A brief summary of these studies is the school is no longer a safe place for students who are studying in the process of achieving its goals. The research findings in several high schools in Jakarta, showed a lack of action or preventive measures carried out by the school. "Hazing" system or bullying that have been entrenched in high school become one of evidence that the school has not been able to carry out their duties to ensure the safety of its students.

Actions taken by the school in addressing the issue of bullying should including preventive measures. However, it is still not well practiced. Some acts of "irregularities" or delinquency is part of the development of the child, but there are some responsibilities that must be paid by the school, for mention the teacher. Their role as one of the core agencies in providing education, does not stop at giving the academic material, but also including the values and social norms. But, in addressing the issue of bullying, the school is not able to act alone. The involvement of parents and teachers need to be able to overcome the problem of bullying in schools. Counseling conducted by the school should also include the role of parents as having the responsibility to ensure the development of the child in order to run properly.

\section{CONCLUSION}

Based on the research conducted by the researchers, bullying as an act that is considered deviant from the norm of the general public has become part of the culture that is embraced by students in high school. The existence of a strong attachment between junior and senior at the school, resulting in the transmission of values "hazing" is easily accepted and entrenched. The activities carried out in schools, one of which interacts with seniors, more time-consuming than the activities carried out at home. Therefore, any engagement between forces more internalized the students in school.

The family who became the primary agent of socialization for the young people should also be actively involved to always give the planting of values and norms that are good for teenagers who are in search of identity. As in common knowledge adolescence need protection and guidance of older adults, including providing input to the culture created by the teenagers.

However, in this research three subjects stated that the parents of each subjects is not too strict in regulating its peer group to be a friend to play and spend time, especially welcome in the school. Moreover, their economic circumstances that can be categorized as families who could afford to make their parent too busy to look for income, so less attention they give to their children in daily basis. Although for subjects number 2 and 3 stated that their activities are done without the knowledge from their parents for various reasons. 


\section{REFERENCES}

Bruce, Steve and Steven Yearley. (2006). "The Sage Dictionary of Sociology". London.

Bryman, Alan. (2004). "Social Research Methods". New York: Oxford University Press.

Bynum, Jack E., W. I. Thompson. (2007). “Juvenile Delinquency: A Sociological Approach". $7^{\text {th }}$ ed. USA: Pearson Education Inc.

Hagan, Frank E. (2011).“Introduction to Criminology: Theories, Methods, and Criminal Behavior”. Sage Publication, Inc. UK:

Jewkes, Yvonne dan Gayle Letherby. (2002). "Criminology: A Reader". USA: Sage Publication.

Narwoko, J.Dwi dan Suyanto, Bagong. (2004). Sosiologi : Teks pengantar \& terapan. Kencana: Jakarta.

Newman, W. Laurance. (1997). Social Research Methods". Qualitative and Quantitative Approaches. 3nd Ed. USA.

Raco.JR. (2001). Metode Penelitian Kualitatif, Jenis Karakteristik dan Keunggulanya. Jakarta: Grasindo.

Rosenbaum, D.P., Lurigio, A.J. and Davis, R.C. (1998). The Prevention of Crime: Social and Situational Strategies. West/Wadsworth: Belmont.

Shoemaker, Donald J. (2010). Theories of Delinquency: An Examination of Explanations Delinquent Behaviour. $6^{\text {th }}$ Ed. USA: Oxford University Press.

Shoemaker, Donald J. (2009). Juvenile Delinquency. UK: Rowman \& Littlefield Publishers, Inc.

Tierney, John. (2006). Criminology: Theory and Context. $2^{\text {nd }}$ ed. UK: Longman.

Whitehead, John T. dan Steven P. Lab. (2013). Juvenile Justice: An Introduction. $7^{\text {th }}$ Ed. China: Anderson Publishing.

Jon Gunnar Bernburg, Marvin D. Krohn, dan Craig J. Rivera. (2006). “Official

Labeling, Criminal Embeddedness, and Subsequent delinquency: A Longitudinal Test of Labeling Theory". Journal of Research in Crimne and Delinquency. Vol 43, No. 1. Sage Publications. 